\title{
8 Protecting livelihood, health, and decency of work
}

\section{Paid domestic workers in times of COVID-19}

\author{
S. Anandhi and E. Deepa
}

\section{Introduction}

The COVID-19 virus, combined with the state measures to contain it through lockdowns, has severely affected one of Chennai's indomitable informal workforces, the paid domestic workers. In the last three decades, Chennai has seen a phenomenal growth of paid domestic work along with the growth of other service sectors. A large section of poor women who live in the slums of the city have taken up paid domestic work as viable employment for their family's survival. There are roughly about 1.8 million poor women in Tamil Nadu who work as paid domestic workers. Their work is primarily a dually informalised work since it is performed in the private informal sphere of the domestic with women who are often invisible as 'workers' in addition to the work being contractual with no employment protection or worker benefits such as the provident fund, health insurance, accident benefits, or old age pension. For example, the paid domestic workers are not covered by the Workmen's Compensation Act as they are not treated as 'workman' by a narrow definition given in this conservative act ${ }^{1}$ that excludes any employment of 'casual nature' or the ones that are not seen as involving 'trade' or 'business'. The paid domestic work is also excluded from a range of worker's protective and welfare acts such as the Minimum Wages Act 1948, Maternity Benefit Act 1961, and the Contract Labour (regulation and Abolition) Act 1970; therefore, they are not entitled to even minimum worker's benefits such as weekly holidays, sick leave, and maternity leave. There is also a problem of fixing the categories of domestic work as skilled and unskilled, with most works being categorised as unskilled, leading to low pay for these workers. For example, in a recent minimum wage notification even cooking, child care, and elderly care have been categorised as unskilled work, leading to low pay for such arduous care work (Sarkar, 2019). The minimum wage fixed by the state of Tamil Nadu for these workers is woefully inadequate, which 
has not taken into account the specific nature of vulnerabilities and the intense physical labour involved in this work. ${ }^{3}$ Working as part-time or full time and as live-in for $8-10$ hours a day either in one house or in multiple houses these workers are subjected to various forms of gendered exploitations, sexual harassment at the workplace, for instance. Further, with their labour being expropriated without adequate compensations or any work security, the livelihood of the domestic workers is extremely fragile and uncertain.

With the pandemic, paid domestic workers are facing the crisis of employment and nonpayment of salary, in addition to the pre-existing social stigmas against them. Some of them are forced to go for work amidst the virus crisis, risking their life with no health security. A large contingent of these women workers belongs to the slums of Chennai with inadequate housing and sanitation facilities and with lack of income to meet any health crisis. Under these abject living conditions, they also share the undue burden of the social distancing policy of the state. Keeping in mind the many woes and challenges faced by the domestic workers during the pandemic, in this chapter, we suggest various measures for social and health protection of these workers along with other labour welfare measures that are on records for many decades without being strictly implemented.

\section{Challenges faced by the paid domestic workers in the context of COVID-19}

\section{Crisis of employment}

The impact of COVID-19 on women domestic workers is profound and sometimes immeasurable. The first major problem faced by these workers is sudden unemployment, which is no less a threat to their lives than the virus itself. In compliance with the lockdown, many employers have requested their domestic workers not to come for work until they are called back (ILO News, 7 May 2020). This has created enormous uncertainty for the paid domestic workers who have begun to fear job loss. A domestic worker from north Chennai, in her interview with us, captured this anxiety thus: 'If I stay at home without work my family will starve, if I leave home defying the lockdown, corona will get me. I dread to think but dared to go for work [uyirai panayam vechuthan velaikku pogiren]' ${ }^{4}$ Though at present we do not have adequate data on the extent of job loss among the paid domestic workers, ${ }^{5}$ the recent protest by the domestic workers belonging to Pen Thozholalar Sangam (Women Workers' Association) and their demand that the state immediately issue an order to the employers to take back the domestic workers make clear that the crisis of job loss is real, 
intense, and that it has severely affected the livelihood of these workers (The Newsminute, 2 September 2020).

Some employers have shrewdly dismissed these workers just before the lockdown and promised to take them back once the lockdown is eased. However, some of these workers are not convinced about getting their jobs back. After 21 days of lockdown, a worker in her interview said that much of her trepidation is about her employers, who might get used to doing their housework by themselves and not call her back and that as they too would get only half pay, they would not pay her salary during the lockdown. 'I am not sure if they will call me back for work [yenna velaikku vetchipaangalaanu theriyala]' was her remark on the plight of unemployment. Several domestic workers in Chennai city have not received their monthly wages for the past two months. Some of them have received only half pay for the month of March and nothing for the following months (Ramakrishnan, 2020). A woman who works for bachelors said her employers paid only half the salary for three months and were also demanding her to be present for work when she faced the problem of transport. According to her, they were also unwilling to advance loan for any health contingency. Some workers have risked police vigilance and, putting their own health at risk, have gone to work so that they do not lose the job. They also undertook more work in these households where the demands of care work as well as sanitation work have increased due to the COVID-19 crisis.

Reverse migration of families in search of rural livelihood have forced some of these domestic workers to leave Chennai without a hope of getting back to their work in the city. Our prediction is that due to job loss in other sectors of informal work, with no employment guarantee scheme for urban workers, there could be a huge supply of domestic workers from poor women seeking job for survival. This would not only increase the competition among the workers but also reduce their bargaining capacity in terms of wages and other benefits, including their capacity to negotiate their demands for toilet facilities within employer's home or for any other health security.

\section{Low pay, liquidity crunch, and welfare crisis}

A large proportion of women domestic workers are middle-aged married women, among whom a substantial number are widows or divorced or living with alcoholic, abusive husbands with financial instability in the family. We may note that men in these families too lack any stable income and most of them are casual workers who work in the informal sector as construction workers, sanitary workers, and so on, or are self-employed as auto drivers, electricians, plumbers, painters, etc. They too have lost their income due 
to the lockdown, thus multiplying the family's hardship. With a monthly income, these women workers are often the main providers for their family and therefore are encountering the worst situation of liquidity crunch in their homes at a time when the cost of essential commodities has gone up and their familiar neighbourhood stores where they have monthly accounts or loans to purchase household items are shut for a while. Some of them told us they could not venture out to borrow money from their employers who could also not transfer the same through phone banking since many of these workers were not familiar with such technologies. The divorced or separated women workers often do not hold ration cards or bank accounts to avail the government welfare schemes during the pandemic.

Pressure to pay rent on time despite the Tamil Nadu Government order (G.O. no.195, 30 March 2020) not to collect rent for these two months has forced many of them to borrow money for high interest. One single woman worker narrated her experience of being harassed by her landlord thus: 'I am living in a hut paying Rs. 2,500 per month as rent. The owner has been harassing me to pay the rent and I had to fight with him two days reminding him of the Government order not to force collect rent. Finally he relented but it is still like a dagger on my neck'. The state welfare provisions, as many pointed out, are not adequate to meet the needs of the entire family. ${ }^{6}$

Though Tamil Nadu Domestic Welfare Board has been allocated special relief funds to manage the crisis of the workers during the pandemic, the Board suffers from long years of inactivity with no proper registration of the domestic workers to deliver the welfare schemes. It is estimated that the Greater Chennai alone would have 5.5 lakh domestic workers, whereas by 2009 , only 64,825 women workers were registered with the Board. Among the registered, only 17,066 members have received any benefits from the Welfare Board and many of them are not even aware of manual workers' welfare schemes.

\section{Return to work: New woes}

In Chennai, ever since the slums have been relocated in faraway Kannagi Nagar and Perumpakkam, the paid domestic workers living in these resettlement colonies travel a long way to the central parts of the city for work, spending a huge amount as transport cost. One may note here that in the case of domestic work, trust, loyalty to employers, and regularity bring the workers several benefits. Therefore, women workers endure long-distance travel to keep their relationship and work intact. In order to retain their work with their previous employers, these workers shell out a huge amount of their salary as travel cost (Coelho et al., 2013). With the easing of the lockdown when these workers were expected to return to work, many of 
them could not do so since their mobility was severely hampered by the lack of transport facilities. The anxiety of losing work due to the lack of transport was expressed thus by a young worker who lives in Perumpakkam and works in Mylapore: 'I do not know what to do. If I do not take up the work when called, the employers might go for other workers and I stand to lose these houses of work. I cannot walk such a long distance for work; I am in a fix and caught in a dilemma [En nilamai, iruthalai kolli erumbu madhiri]'.

\section{Care workers or carriers of virus?}

'Will we come to work with the virus when we care for them? [avangala paathukira nanga noiyoda velaikku varuvoma?]', asked a worker during our interview with her. With the spread of virus, the stigma attached to the domestic work and the workers are reinforced through means of identifying these workers as carriers of virus (Viswanath, 2020). In Chennai, taking into consideration the upper-caste class anxiety about manual workers as being the carriers of any disease, many resident associations have barred entry of domestic workers and drivers into their premises. This is despite the state relaxation of lockdown rules (DT Next, 10 June 2020). Karpagam, a worker from the Pen Thozhilar Sangam, noted that the 'members of Residents' Welfare Associations (RWAs) of various apartments have told them not to visit the apartment for work until next year'. She further observed that the affluent apartment dwellers 'are not ready to take workers who hail from homes in the Tamil Nadu Slum Clearance Board' (The Newsminute, 2 September 2020). Similarly, A. Kumari, who works for several houses in an apartment complex, said that she was asked to leave immediately once the employers got to know that she lives in the Tamil Nadu Slum Clearance Board tenements in Perumbakkam (The Hindu, 3 September 2020). 'It has been three months and I am struggling to find a job', she said. In cases where they have been called back to work, severe restrictions and surveillance are put in place to the extent of denying the dignity of the workers. One worker confided that after the lockdown, new kinds of surveillance practices are put in place in her employer's house, making her feel uneasy and self-conscious about her hygiene status. 'Interrogating me as to whether I keep my house clean and whether everyone at home bathed, etc., in addition to the routine wash of my feet with turmeric water before entering their house have become a new routine making me feel conscious of my working class status'. Another worker felt that though maintaining hygiene and self-distancing are good to keep the virus away it should not be used to stigmatise or cast aspersions on the workers. In some residential apartments domestic workers are prohibited from using the lift to reach houses in several floors. So far it appears that instructions on maintaining social 
distancing given to these workers is used in subtle ways to reinforce the pre-existing stigmas against the workers who seem to risk their own life for want of adequate provisions for hand-washing, self-isolation, and wearing of masks or any other personal protective gears.

\section{Paid domestic workers and the unpaid care work}

The COVID-19 pandemic has revealed the persistent inequality in the gender distribution of unpaid care work with all of them indicating the unusual burden of domestic responsibilities with no assistance from men in doing household chores. ILO observes that prior to the COVID-19 crisis, over two third of 16.4 billion hours were spent by women in unpaid care work every day across the world. This has now increased manifold (ILO Brief, 2020a). This is more so in the case of poor domestic workers whose low pay and temporary employment has always undermined their capacity to hire paid labour to do care work in their families, thus adding to their paid care work responsibilities. During the lockdown and due to the pandemic, this unpaid care work in their own houses has intensified for the paid domestic workers. The absence of day care centres, schools and permanent presence of unemployed men demanding care along with the elderly care and increasing attention to sanitation have added to the woes of domestic workers doing unpaid family work. In addition, there are everyday ordeals of erratic water supply, lack of transport, lack of time to access ration shops, public hospitals, and corporation dispensaries faced by these workers.

Altogether, COVID-19 has exacerbated the crisis of existence for women domestic workers with their lack of access to labour and social protection including health care and maternity protection, especially when many of them with their reduced immunity are forced to work even under such life threatening conditions. Therefore, these women workers are, as ILO observes, likely to be more impoverished and marginalised from income replacement and from social protection schemes than the formal workers. It is also worth taking note of ILO's warning on lockdown measures here. It has said, '[1] ockdown measures will worsen poverty and vulnerabilities among the world's two billion informal economy workers' (ILO, 2020b).

\section{Need for a coordinated social and health policy for domestic workers}

More than ever before, in the present context of the pandemic it becomes important to recognise the domestic workers' economic productivity and their right to a safe healthy working environment. The state must take 
effective measures in this direction. Incidentally, India has not even ratified the ILO Convention on Domestic Workers which mandates nations to provide occupational safety and health of these workers (ILO Domestic Workers Convention, 2011).

Given the vulnerability of paid domestic workers, prioritising monetary and health support along with meeting their immediate needs becomes a state responsibility. In particular, the state has to attend to their special needs of sanitation and health care and evolve specific social protection schemes. About ten Central Trade Unions in India have already demanded immediate measures from the state to protect the livelihood of vulnerable workers in the informal sector including the migrant workers and for the inclusion of trade unions in the COVID-19 response task force. The Central government so far has not responded to these demands (ILO, 2020b).

\section{Rethinking the role of Tamil Nadu Domestic Workers' Welfare Board}

In consonance with the demands of the trade unions, the Tamil Nadu Domestic Welfare Board may initiate few consultative processes with trade unions that work for the welfare of domestic workers and include them as part of the task force to address the specific needs of the domestic workers. In this regard, the Board must recognise specific gendered nature of discriminations and exclusions that are faced by these workers during the pandemic in order to prioritise their occupational health and livelihood issues (ILO Brief, 2020b). In this regard ILO guideline on this might help the state to evolve a coordinated health and social policy: '[s]trengthening occupational safety and health, adjusting work arrangements, preventing discrimination and exclusion, and providing access to health care and paid leave (and also to food and social services for the most vulnerable) are all indispensable strands of a coordinated health and social policy response to the crisis' (ILO Policy Brief on Covid-19, Pillar:3). Treating domestic workers as essential service workers and providing them with necessary personal protective equipment along with reliable and accessible information and affordable health services is the responsibility of the Tamil Nadu Domestic Workers' Welfare Board, who can be helped by the domestic workers' unions. Simple measures like having mobile COVID-19 testing centres placed in various public places where the workers could easily get tested will help them and the state to contain the spread of virus. Similar such demands have been placed by the International Domestic Workers' Federation (IDWF, 18 March 2020).

Established in 2007, the Tamil Nadu Domestic Workers' Welfare Board offers a range of financial assistance to the registered domestic workers ranging 
from children's education, marriage, and maternal health expenses of the workers, death-related benefits for the worker's heir, a nominal pension amount, and so on. Unfortunately, the Welfare Board has not even paid attention to the compulsory registration of all domestic workers to benefit from these schemes. Domestic workers are not even aware of the existence of the Board. For this, the Board must adequately publicise their activities and schemes and evolve new norms and rules for compulsory registration of the workers.

In fixing the minimum wages for the domestic workers, the state has overlooked the problem of fixing the categories of domestic work as unskilled labour - cooking and childcare for instance - leading to low pay for these essential care workers. All these have serious implications for the dignity and decency of work for the domestic workers.

Being in informal work, no domestic worker has any legal entitlement to sickness leave benefits. In the present context of COVID-19, as ILO has pointed out, there is a need for a coordinated health and social welfare response to the crisis so that the state can ensure occupational safety, better working environment for these workers without discrimination and exclusion (ILO Policy Brief on Covid 19, Pillar: 3). To address specific health needs of the workers in times of pandemic like this, employers should be made to pay a nominal amount towards insurance scheme or other benefits for the workers.

Work from home (WFH) policy, mainly for the private-sector employees, may affect the paid domestic workers who work in such houses, as some workers anticipate increasing workloads with houses multiplying as office space with no additional wage for doing any extra cleaning or sanitation work. Some workers even expressed their anxiety about working for houses with bachelors who would be working from home. ${ }^{7}$ Extending the laws related to sexual harassment at work to the domestic work sphere and improving wages for the increasing workload would enable these workers to feel safe at work. As we noted elsewhere, two legislations concerning domestic workers, The Unorganised Workers' Social Security Act, 2008 and The Sexual Harassment of Women at Workplace (Prevention, Prohibition and Redressal) Act, 2013, at present are inadequate in addressing the specific forms of exploitations peculiar to this work (Rajkotwala and Mehta, 2020).

With the postponement of school education, the likelihood of inducing young girls into paid domestic work will result in an increase in child labour in small towns and in rural Tamil Nadu (Kundu, 21 April 2020). Providing accessible technology-based educational solutions for vulnerable families could become an important solution to mitigate the problem of child labour (ILO Brief 2020a \& 2020b).

As long-term measures to mitigate the vulnerability of paid domestic workers, ${ }^{8}$ following steps can be taken by the state through the Domestic Welfare Board: 
1) Formalisation of the domestic work sector through mandatory registration of domestic workers with the corporation divisions/wards.

2) Employment of only registered domestic workers and punitive measures for employers violating such norms. As the trade unions perceive such registration to have a benefit to both employer and domestic worker, it is a workable option.

3) Registered workers should be entitled to (a) living wage (time-rated or job-specified wages) to be fixed by the labour department; (b) decent working conditions to be clearly laid out; (c) guidelines for treatment of domestic workers; (d) leave, annual bonus, transport, etc., as part of the contract; (e) right to associate and freedom to participate in union activities; (f) right to access good public health centres near their homes; (g) right to information related to their welfare provided by the government through the Domestic Workers' Welfare Board.

4) The state could additionally levy tax through corporation to cover the cost of social security and insurance. The money collected from worker, employer, and the additional levies could form part of the Domestic Workers Fund. The existing Domestic Workers' Welfare Board could be the nodal body for the welfare and oversight.

5) Mandatory savings could be introduced through means of some cooperative efforts which might enable the domestic workers to utilise, borrow, and lend to other women during this kind of crisis.

6) Housing security could be provided for women workers to avoid eviction threat by landlords, state, and lenders. This is especially important in the light of rural migrant workers selling their small-sized patta lands in the village to buy non-patta land in the city for their permanent dwelling with little housing security.

7) Displacement of workers within the city which has huge social, economic, and health cost for the workers should be stopped.

For carrying out some of these welfare measures, the state Domestic Workers' Welfare Board could collaborate with Penn Thozhilalargal Sangam, Centre for Women's Development and Research (CWDR, Chennai), and ILO, Decent Work Program, Delhi, to create a framework or guidelines in the light of the present crisis and to look into aspects of laws, and their implementation.

\section{$* * *$}

Acknowledgements: We thank Sujatha Mody, Renuka Bala, and Karen Coelho for their valuable inputs, comments, and suggestions. Usual caveats apply. 


\section{Notes}

1 According to this central government act, 'workman' connotes 'any person other than a person whose employment is of a casual nature and who is employed otherwise than for the purposes of the employer's trade or business'. The Act's definition of an employer and the contract labour though clearly applies to the paid domestic workers and their employers, the provisions of the Act have not been extended to cover the paid domestic work. See, 'The Workmen's Compensation Act, 1923', https://indiankanoon.org/doc/1806623/. (accessed on 20 October 2020).

2 Applying this Act to paid domestic work would have helped regulate this contractual work since one of the regulatory requirements under this statute include registration of the principle employer and the issue of licence to recruitment agencies as contractors. As of now these provisions exist only for work that involves establishments in which 20 or more workers are employed as contract labour and that they do not apply to 'establishments in which work only of an intermittent or casual nature is performed'.

3 In 2018, the Tamil Nadu government has fixed their minimum wage at Rs. 37 per hour and the monthly minimum wage at Rs.6,836 for 8 hours of work per day.

4 We have carried out few tele-interviews with a small number of domestic workers from north, south, and central Chennai and also received notes on challenges faced by the domestic workers during COVID-19 from domestic workers' forums led by Pen Thozhilalar Sangam (north Chennai) and Manushi, Centre for Women's Development Research (Greater Chennai Corporation).

5 In an informal chat, Sujatha Mody, an activist scholar with Pen Thozhilalar Sangam, claimed that more than 80 per cent of the women domestic workers of Chennai were not paid salary for at least two months during the lockdown.

6 Those with a ration card have received an allowance of Rs.1,000 along with substandard rice and lentils. This is not adequate for even a small family.

7 A domestic worker who works for the bachelor IT workers said that previously she used to enter their house only after they have left for work and therefore felt comfortable working for them. She expressed her fear that they might make it inconvenient for her to work when they are present in the house all the time and without any woman employer around in the house.

8 The ILO labour standards on employment, social protection, wage protection, and workplace cooperation already contain specific guidance on policy measures for various sets of workers such as paid domestic workers affected by COVID-19 related crisis. While drawing up our specific suggestions we have kept this in mind. See, 'ILO Standards and COVID-19 (coronavirus): Key provisions of international labour standards relevant to the evolving COVID-19 outbreak', https://www.ilo.org/wcmsp5/groups/public/---ed_norm/---normes/ documents/genericdocument/wcms_739937.pdf. (accessed on 15 June 2020).

\section{References}

Coelho, Karen, T. Venkat and R. Chandrika. 2013. 'Housing, homes and domestic work: A study of paid domestic workers from resettlement colony in Chennai', Economic and Political Weekly, Vol. 48, No. 43. 
DT Next. 2020. 'Residential colonies debate on allowing domestic helps to enter', June 10. https://www.dtnext.in/News/City/2020/05/04065718/1228201/Resident ial-colonies-debate-on-allowing-domestic-helps-.vpf (accessed on 15/6/2020).

IDWF. 2020. 'International domestic worker's federation statement on protecting domestic workers rights and fighting the Corona Virus pandemic', Mar 18. https ://idwfed.org/en/updates/global-idwf-statement-on-protecting-domestic-worke rs-rights-and-fighting-the-coronavirus-pandemic (accessed on 7/6/2020).

ILO. 2020a. 'ILO standards and COVID-19 (coronavirus): Key provisions of international labour standards relevant to the evolving COVID-19 outbreak', May 29. https://www.ilo.org/global/standards/WCMS_739937/lang--en/index.h tm (accessed on 15 June 2020).

ILO. 2020b. 'COVID-19 and the world of work: Country policy responses', October 9. https://www.ilo.org/global/topics/coronavirus/country-responses/lang--en/in dex.htm\#IN (accessed on 20/10/2020).

ILO. n.d. 'Policy brief on COVID-19: Pillar 3: Protecting workers in the workplace', https://www.ilo.org/global/topics/coronavirus/impacts-and-responses/WCMS 739049/lang--en/index.htm (accessed on 16/6/2020).

ILO Brief. 2020a. 'COVID-19 crisis and the informal economy: Immediate responses and policy challenges', May 5. https://www.ilo.org/global/topics/e mployment-promotion/informal-economy/publications/WCMS_743623/lang-en/index.htm (accessed on 14/6/2020).

ILO Brief. 2020b. 'The COVID-19 response: Getting gender equality right for a better future of women at work', May 11. https://www.ilo.org/global/topics/c oronavirus/WCMS_744685/lang--en/index.htm (accessed on 15/6/2020).

ILO Domestic Workers Convention. 2011. No. 189, Article 13. https://www.ilo.org/ dyn/normlex/en/f?p=NORMLEXPUB:12100:0::NO::P12100_INSTRUMENT ID:2551460 (accessed on 13/6/2020).

ILO News. 2020. 'Contagion or starvation, the dilemma facing informal workers during the COVID-19 pandemic', May 7. https://www.ilo.org/global/about-th e-ilo/newsroom/news/WCMS_744005/lang--en/index.htm (accessed on 15/6/ 2020).

Kundu, Protiva. 2020. 'COVID-19 crisis will push millions of children into child labour', Wire, April 21. https://thewire.in/rights/covid-19-crisis-will-push-mil lions-of-vulnerable-children-into-child-labour (accessed on 13/6/2020).

Rajkotwala, Mustafa and Rahil Mehta. 2020. 'Lockdown woes : The dismal state of domestic workers in India', Jurist, May 6. https://www.jurist.org/commentary/t ag/author-mustafa-rajkotwala-and-rahil-mehta/ (accessed on 16 /6/2020).

Ramakrishnan, Susmitha. 2020. 'With no pay, hopes dry up for domestic helps in Chennai', The New Indian Express, June 12. https://www.newindianexpress.c om/cities/chennai/2020/may/18/with-no-pay-hopes-dry-up-for-domestic-helps-i n-chennai-2144681.html (accessed on 16/6/2020).

Sarkar, Kingshuk. 2019. 'Complexity in the determination of minimum wages for the domestic workers in India', NLI Research Studies Series, 137/2019. https ://vvgnli.gov.in/sites/default/files/137-2019-Kingshuk_Sarkar.pdf (accessed on $14 / 6 / 2020)$. 
Tamil Nadu Government. 2020. Revenue and Disaster Management (DMII) Department, G.O (D) No. 195. March 30. https://tnsdma.tn.gov.in/app/webroot/ img/covid_19/gos/lockdown/G.O.195.pdf (accessed on 20/10/2020).

The Hindu. 2020. 'Domestic workers in Chennai face stigma, many are left without jobs', September 3. https://www.thehindu.com/news/national/tamil-nadu/domes tic-workers-in-chennai-face-stigma-many-are-left-without-jobs/article325133 38.ece (accessed on $15 / 9 / 2020$ ).

The Newsminute. 2020. 'Facing job loss and stigma, hundreds of domestic workers protest in Chennai', September 02. https://www.thenewsminute.com/article/fa cing-job-loss-and-stigma-hundreds-domestic-workers-protest-chennai-132111 (accessed on 15/9/2020).

Viswanath, Kalpana. 2020. 'It is time to stop seeing domestic workers as COVID-19 carriers', The Wire, May 27. https://thewire.in/labour/covid-19-lockdown-domes tic-workers (accessed on 15/6/2020). 